ISSN 0258-7122 (Print), 2408-8293 (Online)

Bangladesh J. Agril. Res. 44(4): 669-677, December 2019

\title{
EVALUATION OF PLANT EXTRACTS, FUNGICIDES, BIO-AGENT AND SOIL AMENDMENTS AGAINST FOOT AND ROOT ROT DISEASE OF BETELVINE CAUSED BY SCLEROTIUM ROLFSII UNDER FIELD CONDITION
}

\author{
M. H. RAHMAN ${ }^{1}$, M. R. ISLAM ${ }^{2}$, F. M. AMINUZZAMAN ${ }^{3}$ \\ A. LATIF $^{4}$ AND S. NAHAR ${ }^{5}$
}

\begin{abstract}
The studies were carried out on the management of foot and root rot disease caused by Sclerotium rolfsii Sacc. of betelvine (Piper betle L.) during April, 2017 to April, 2018 in a betelvine orchard (baroj) in the experimental farm of Sher-e-Bangla Agricultural University, Dhaka. There were 10 treatments, namely Provax 200, Tilt 250 EC, Score 250 EC, Pencozeb 80 WP, Garlic clove extract, Allamanda leaf extract, Poultry waste, Vermi-compost, Trichoderma harzianum and Control. The in-vivo evatuation, plant was inoculated by $S$. rolfsii after six month of plantation. The evaluation revealed that the lowest disease incidence of $8.33 \%$ was found in Provax 200 whereas the highest disease incidence of 91.67 was recorded under the untreated control treatment. The maximum of $90.91 \%$ reduction in disease incidence over control was found under Provax 200, which was significantly higher compared to all other treatments. Among the treatments, Provax 200 was noted as the most effective fungicide followed by Score $250 \mathrm{EC}$. The highest yield $(7.57 \mathrm{t} / \mathrm{ha})$ at 120 days after inoculation was found in case of Provax 200 which was $330.1 \%$ increased over untreated control. Stem and soil treated with Provax 200 including spraying at 3 days after inoculation, then sprayed at 7 days' intervals minimized disease incidence and increased yield. Among the eco-friendly approach, Garlic clove extract, Trichoderma harzianum and soil amended with Vermi-compost also showed better performance in controlling foot and root rot disease of betelvine as compared to control.
\end{abstract}

Keywords: Betelvine, disease management, foot and root rot, Sclerotium rolfsii.

\section{Introduction}

Betelvine (Piper betle L.), vernacularly known as 'Pan', is a kind of dioecious perennial creeper vine belonging to the family Piperaceae. It is cultivated largely for its leaves. It is an important cash crop of Bangladesh. Betel leaves have a strong pungent aromatic flavor and are widely used as masticatory. Mature leaves are used for chewing with smeared hydrated lime and catechu, arecanut,

${ }^{1}$ Regional Agricultural Research Station, Bangladesh Agricultural Research Institute (BARI), Cumilla, ${ }^{2 \& 3}$ Department of Plant Pathology, Sher-e-Bangla Agricultural University, Dhaka, ${ }^{4}$ Department of Entomology, Sher-e-Bangla Agricultural University, Dhaka, ${ }^{5}$ Senior Assistant Director, NATA, Bangladesh. 
cardamom, clove, etc. Betelvine leaf chewing is considered as a good and cheap source of dietary calcium. Usually the people of South-Asia, South-east Asia, Gulf States and Pacific Islands chew betel leaves. All classes of people of Bangladesh chew not only as a habit but also as an item of rituals, etiquette and manners. There are about 100 varieties/cultivars of betelvine in the world (Guha and Jain, 1997). Among the cultivars, Desi Bangla, Bangla, Kali Bangla, Jhali, Sanchi, Goyeshi, Bhabna, Mitha, Geso, Bonhoogly, etc., are found to be widely grown in Bangladesh. Total cultivated area under the crop in Bangladesh in 2016-17 was about 23,803.20 hectares and the total annual production was about 2,14,252 metric tons. The average yield per hectare is 9.0 metric tons (BBS, 2018). Pan leaf is usually plucked throughout the year but maximum production obtained in the months of July to October.

The acreage of betelvine is decreasing gradually due to infestation of disease and pest (Islam, 2005) and the extent of losses varies from 5-90 percent (Dasgupta and Sen, 1999; Dasgupta et al., 2005). Among the diseases of betelvine foot and root rot caused by Sclerotium rolfsii is the most overwhelming disease which decreases the production of betel leaf to a great extent (Islam, 2005). Humid and moist shaded conditions are favorable for betelvine growth which also favor a variety of root and foliage disease development (Goswami et al., 2002). The fungus can overwinter as mycelium in infected tissues or plant debris or as sclerotia near soil surface or buried in soil which serve as a major source of primary infection by germinating in response to alcohols and other volatile compounds released from decomposing plant material (Punja, 1985).

At present diseases are mainly managed by the use of chemicals such as fungicides. However, the indiscriminate use of chemicals not only hazardous to living being but also break the natural ecological balance by killing the beneficial and/or antagonist microorganisms. On the other hand, Botanical extracts, Plant growth promoting fungi (PGPF) and soil amended materials etc. suppress the pathogen and protect the plants that is environmentally safe, durable and cost effective alternative to chemicals (Mukhopadhyay, 1994) and avoid the development of resistant strains of the pathogen.

Hence, efforts have to be made to retain pathogen activity below economic threshold level by choosing different alternative methods. So, the present experiment was conducted to evaluate the efficacy of four fungicides [Provax 200 (Carboxin 17.5\%+ Thiram 17.5\%), Tilt 250 EC (25\% Propiconazole), Score 250 EC (25\% Difenconazole) and Pencozeb 80 WP (80\% Mancozeb)], two botanicals [Garlic clove extract (allicin), Allamanda leaf extract (allamandin)], two soil amendments [Poultry waste, Vermi-compost] and one bio-agent (Trichoderma harzianum) for controlling foot and root rot disease of betelvine caused by $S$. rolfsii in field condition. 


\section{Materials and Methods}

The experiment was conducted in a betelvine orchard (baroj) in the experimental farm of Sher-e-Bangla Agricultural University (SAU), Dhaka during April, 2017 to April, 2018. The experiment was laid out in RCBD with 4 replications maintaining plot size $(0.30 \times 0.60) \mathrm{m}^{2}$ and plant to plant spacing $20 \mathrm{~cm}$. One hill with three plants were used for each treatments. Altogether 10 treatments comprising fungicides, botanicals, bio-agent and soil amendments were tested in the experiment. The treatments were $\mathrm{T}_{1}=$ Provax $200 @ 0.25 \%, \mathrm{~T}_{2}=$ Tilt- $250 \mathrm{EC}$ @ 0.1\%, $\mathrm{T}_{3}=$ Score $250 \mathrm{EC} @ 0.05 \%, \mathrm{~T}_{4}=$ Pencozeb $80 \mathrm{WP} @ 0.45 \%, \mathrm{~T}_{5}=$ Garlic clove extract @15\%, $\mathrm{T}_{6}=$ Allamanda leaf extract @ 15\%, $\mathrm{T}_{7}=$ Vermicompost @30g/plant, $\mathrm{T}_{8}=$ Poultry manure @30g/plant, $\mathrm{T}_{9}=$ Trichoderma harzianum@5g/plant and $\mathrm{T}_{10}=$ Control.

\section{(a) Growing of betelvine cuttings}

A piece of medium high land with well drainage system was selected and deep ploughing was done during early summer at the end of April month in 2017. After ploughing, upper soil is left exposed in the sun for two months. During the first week of June, three times ploughing was done for well pulverized good tilth condition of soil. Weeds and stubbles were removed manually. Drainage trenches of $90 \mathrm{~cm}$ width by $15 \mathrm{~cm}$ depth were dugged in between two adjacent beds. A suseptible betelvine cultivar Misti pan cutting was collected from 3-5 years old betelvine orchared in Rajshahi. Forty centimeter long cuttings with three to five nodes were cut from the vine. For each treatment, twelve betelvine cuttings were treated deeply into suspension of fungicides, plant extracts and bioagent separately for 20 minutes. The cuttings were then drained off, air dried and planted in the field. For control treatment the cuttings were treated with plain water.

Treated vine cuttings were planted in the experimental field under partially shaded and humid environment in the betelvine baroj. Planting was done with the help of khurpi (a hand operated implement). For planting, a hole was made with khurpi, so that the internodes below the bud point is dipped in soil, but rest part of cutting must be touching with surface soil. The cuttings were planted in the furrows at 8-10 $\mathrm{cm}$ deep. The hole was compacked with the help of thumb finger. The planted cuttings were watered twice a day until the vines were established. Sticking of vines, irrigation and fertilization/manuring were done as per requirement of the orchard. Weeding was done regularly to ensure weed free clean cultivation.

\section{(b) Inoculum preparation and inoculation of $S$. rolfsii}

The isolate of $S$. rolfsii isolated from foot and root rot infected betelvine following tissue planting method (Mian, 1995) and multiplied on barley grains (Gupta and Kolte, 1982). Fresh barley grains were pre-soaked in 2\% sucrose 
solution overnight, drained off excess solution and boiled in fresh water for 30 minutes and drained off again. These were transferred into $250 \mathrm{ml}$ conical flasks @ $80 \mathrm{~g}$ and autoclaved at $121.6^{\circ} \mathrm{C}$ temperature, under $1.1 \mathrm{~kg} / \mathrm{cm}^{2}$ pressure for 20 minutes. The conical flasks were allowed to cool at room temperature and were inoculated with $5 \mathrm{~mm}$ discs of 3 to 4 days old culture of $S$. rolfsii grown on PDA. Seven discs per flask were added and flasks were incubated for three weeks at $25 \pm 2^{\circ} \mathrm{C}$.

After six months of plantation of betelvine the isolate of causal pathogen $(S$. rolfsii) were inoculated. The plants were prepared for inoculation by removing top soil around $5 \mathrm{~cm}$ of the stem to a depth of $2 \mathrm{~cm}$. A table spoon $(5 \mathrm{~g})$ of inoculum was placed in direct contact of entire circumference of the exposed stem. Finally, the inoculum was lightly covered with top soil for infection.

\section{(c) Collection and preparation of plant extracts}

The plant leaf extracts were prepared by using the method of Ashrafuzzaman and Hossain (1992). For preparation of extracts, collected leaves were weighted in an electric balance and then washed in tap water and then in distilled water. After washing the big leaves were cut into small pieces. For getting extract, weighted plant parts were blended in an electric blender and then distilled water was added into the jug of the blender. For getting 1:1 (w/v) ratio $100 \mathrm{ml}$ of distilled water was added with $100 \mathrm{~g}$ plant parts. The pulverized mass was squeezed through 3 folds of fine cotton cloth. The extract was used as stock solution for the study. To prepare $15 \%$ concentrations of plant extract, $15 \mathrm{ml}$ of stock solution was mixed with $85 \mathrm{ml}$ of sterilized water. The $15 \%$ concentrations of plant extract was used for application.

\section{(d) Preparation of bio-agent}

The fungal antagonist bio-agents, Trichoderma harzianum collected from the laboratory of Plant Pathology Division, Bangladesh Agricultural Research Institute (BARI) and cultured on PDA. Inoculum of the bio-agent, T. harzianum was prepared using the method as described by Gupta and Kolte (1982). Fresh barley grains were pre-soaked in $2 \%$ sucrose solution overnight, drained off excess solution and boiled in fresh water for 30 minutes and drained off again. These were transferred into $250 \mathrm{ml}$ conical flasks @ $80 \mathrm{~g}$ and autoclaved at $121.6^{\circ} \mathrm{C}$ temperature, under $1.1 \mathrm{~kg} / \mathrm{cm}^{2}$ pressure for 20 minutes. The conical flasks were allowed to cool at room temperature and were inoculated with $5 \mathrm{~mm}$ discs of 3 to 4 days old culture of $T$. harzianum grown on PDA. The inoculated flasks were incubated at $25 \pm 2^{0} \mathrm{C}$ for three weeks.

\section{(e) Spraying of fungicides and plant extracts}

Fungicides (Provax $200 @ 0.25 \%$, Tilt-250 EC @ 0.1\%, Score 250 EC @ 0.05\%, Pencozeb 80 WP @ 0.45\%) and plant extracts solutions were prepared 
separately. The selected plant extracts and fungicides were sprayed at 3 days after inoculation at the base of the plant and plant base soil. Then sprayed at 7 days' intervals for three times by hand sprayer. Precautions were taken to avoid drifting of spray materials to neighboring plants.

\section{(f) Application of bio-agent, poultry manure and vermi-compost}

A table spoon ( $5 \mathrm{~g}$ ) of cultured $T$. harzianum on barley grains were applied at the base and root zone of the plants before 10 days of $S$. rolfsii inoculation. Similarly, poultry manure $30 \mathrm{~g}$ and vermi-compost $30 \mathrm{~g}$ per plant were applied seperately on different plant at the base and root zone before 10 days of $S$. rolfsii inoculation. Precautions were taken to avoid drifting of application materials to the neighboring plants.

\section{(g) Data collection}

The data on days required for appearance of disease symptom, disease incidence and yield of betel leaf were recorded.

The incidence of the disease was computed based on the following formula:

$\%$ Disease incidence $=\frac{\text { Number of infectedplantin thearea covered }}{\text { Number of inspectedplant }} \times 100$

The yield increase was calculated using the following formula:

$\%$ yield increase over control $=\frac{x-y}{y} \times 100$

Where $\mathrm{x}=$ Mean under treatments $\left(\mathrm{T}_{\mathrm{n}, \mathrm{n}=1-9}\right)$ and $\mathrm{y}=$ Mean under control $\left(\mathrm{T}_{10}\right)$

\section{(h) Statistical analysis}

The data were statistically analyzed by using computer package program (Statistix 10). The significant differences of the treatment means were compared by Duncan's Multiple Range Test (DMRT) at 1\% level of significance.

\section{Results and discussion}

\section{(A) Days required for appearance of disease symptom}

Appearance of foot and root rot disease in inoculated betelvine varied from 10 to 95 days among the treatments (Table 1). Disease symptom appeared at 10 days in the control treatment while it ranged from 29 to 95 days among the treated plots. The result indicated that the appearance of foot and root rot disease could be deferred or delayed by the application of different treatment with fungicides, botanicals, bio-agent and soil amendments. 


\section{(B) Disease incidence}

The highest disease incidence ranging from 58.33 to $91.67 \%$ was observed in control treatment at 30 through 120 DAI (Table 1). The disease incidence increased gradually with the progress of duration after inoculation showing the maximum of $91.67 \%$ at 105 and 120 DAI. Application of different treatments significantly reduced the disease incidence over control.

No visible symptoms of foot and root rot of betelvine appeared at 30 DAI, in case of fungicides, botanicals, bio-agents and soil amendments. Though poultry manure and control treated plot showed the disease incidence $16.67 \%$ and $58.33 \%$, respectively.

At 45 DAI, the minimum of $16.67 \%$ disease incidence was recorded in case of treatment $\mathrm{T}_{7}$ followed by $\mathrm{T}_{8}$. At $60 \mathrm{DAI}$, the disease incidence was absent under $\mathrm{T}_{1}, \mathrm{~T}_{2}, \mathrm{~T}_{3}, \mathrm{~T}_{5}, \mathrm{~T}_{6}$ and $\mathrm{T}_{9}$. No disease incidence was observed at $75 \mathrm{DAI}$ in $\mathrm{T}_{1}, \mathrm{~T}_{2}$, $\mathrm{T}_{3}, \mathrm{~T}_{5}$ and $\mathrm{T}_{9}$. At that stage the lowest incidence of $16.16 .67 \%$ was recorded from $\mathrm{T}_{6}$ which was statistically similar to $\mathrm{T}_{4}$ but significantly higher as compared to $\mathrm{T}_{7}$ and $\mathrm{T}_{8}$. At $90 \mathrm{DAI}$, only $\mathrm{T}_{1}$ and $\mathrm{T}_{5}$ showed no incidence of disease. At that stage the disease incidence under $T_{2}, T_{4}, T_{7}$ and $T_{8}$ were statistically similar but significantly higher as compared to $\mathrm{T}_{6}$ and $\mathrm{T}_{9}$ (Table 1 ). At $105 \mathrm{DAI}$, minimum of $8.33 \%$ foot and root rot incidence of betevine was found under $\mathrm{T}_{1}$, which were statistically similar to $\mathrm{T}_{3}$ and $\mathrm{T}_{9}$.

At $120 \mathrm{DAI}$, the lowest disease incidence of $8.33 \%$ was recorded from $\mathrm{T}_{1}$, which was statistically similar to only $\mathrm{T}_{3}(16.67 \%)$ but significantly higher as compared to other treatments. The disease incidence was $33.33 \%$ in the treatments $\mathrm{T}_{2}, \mathrm{~T}_{5}$ and $\mathrm{T}_{9}, 49.99 \%$ under $\mathrm{T}_{6}, 58.32 \%$ in $\mathrm{T}_{7}$ and $66.66 \%$ in $\mathrm{T}_{4}$ and $\mathrm{T}_{8}$ (Table 1).

At 120 days after inoculation (DAI), the maximum of $90.91 \%$ reduction in disease incidence over control was found under $\mathrm{T}_{1}$, which was statistically similar to only $\mathrm{T}_{3}(81.82 \%)$ but significantly higher as compared to all other treatments (Fig. 1). The lowest reduction was found under $\mathrm{T}_{4}(18.95 \%)$ followed by $\mathrm{T}_{8}, \mathrm{~T}_{6}$ and $\mathrm{T}_{7}$. The disease incidence was 63.64 under treatments $\mathrm{T}_{2}, \mathrm{~T}_{5}$ and $\mathrm{T}_{9}$ which were significantly higher as compared to $\mathrm{T}_{4}, \mathrm{~T}_{6}, \mathrm{~T}_{7}$ and $\mathrm{T}_{8}$. Among the treatments, $T_{1}$ i.e. Provax 200 was noted as the most effective fungicide followed by $\mathrm{T}_{3}$ i.e. Score $250 \mathrm{EC}$ in controlling foot and root rot disease of betelvine.

\section{(C) Yield}

The per hectare yield of betel leaf at 120 days after inoculation was 7.57, 7.24, 7.16, 7.14 and 6.59 tons under the treatments of Provax $200\left(\mathrm{~T}_{1}\right)$, Score $250 \mathrm{EC}$ $\left(\mathrm{T}_{3}\right)$, T. harzianum $\left(\mathrm{T}_{9}\right)$, Garlic clove extract $\left(\mathrm{T}_{5}\right)$ and Tilt-250 EC $\left(\mathrm{T}_{2}\right)$, respectively (Table 2). The lowest yield of $1.76 \mathrm{t} / \mathrm{ha}$ was found under control $\left(T_{10}\right)$ followed by Poultry manure $\left(T_{8}\right)$, Allamanda leaf extract $\left(T_{6}\right)$. 
Application of Provax 200, Tilt-250 EC, Score 250 EC, Garlic clove extract and Trichoderma harzianum, produced increased yield over control ranged from 274.4 to $330.1 \%$. These five treatments were noted as effective treatments to control the disease.

The results of the present investigation were in agreement with findings of many other researchers. Carboxin (Provax 200/ Vitavax 200) reported to be effective in controlling collar rot of Sunflower and Sunhemp caused by S. rolfsii (Pal and Choudhary, 1983). Others reported that Garlic clove extract found effective both in-vitro and in-vivo in controlling foot and root rot of betelvine (Yasmin, 2016; Shahiduzzaman, 2015). As a bio-agent $T$. harzianum and $T$. viride were also proved to be highly promising against soil borne pathogen, $S$. rolfsii (Rekha et al., 2012; Parvin et al., 2016).

Table 1. Effect of fungicides, plant extracts, bio-agent and soil amendments on the incidence of foot and root disease of betelvine under field condition

\begin{tabular}{|c|c|c|c|c|c|c|c|c|}
\hline \multirow[t]{2}{*}{ Treatments } & \multirow[t]{2}{*}{ DDI } & \multicolumn{7}{|c|}{$\begin{array}{l}\text { Percent disease incidence (PDI) at different days after inoculation } \\
\text { (DAI) }\end{array}$} \\
\hline & & 30 DAI & 45 DAI & 60 DAI & 75 DAI & 90 DAI & 105 DAI & 120 DAI \\
\hline $\mathrm{T}_{1=} \operatorname{Provax} 200$ & 95 & $\begin{array}{c}0.00 \mathrm{c} \\
(0.083)\end{array}$ & $\begin{array}{r}0.00 \mathrm{~d} \\
(0.083)\end{array}$ & $\begin{array}{r}0.00 \mathrm{c} \\
(0.083)\end{array}$ & $\begin{array}{r}0.00 \mathrm{~d} \\
(0.083)\end{array}$ & $\begin{array}{c}0.00 \mathrm{e} \\
(0.083)\end{array}$ & $\begin{array}{l}8.33 \mathrm{e} \\
(8.57)\end{array}$ & $\begin{array}{l}8.33 \mathrm{e} \\
(8.57)\end{array}$ \\
\hline $\mathrm{T}_{2}=$ Tilt $-250 \mathrm{EC}$ & 76 & $\begin{array}{c}0.00 \mathrm{c} \\
(0.083)\end{array}$ & $\begin{array}{r}0.00 \mathrm{~d} \\
(0.083)\end{array}$ & $\begin{array}{c}0.00 \mathrm{c} \\
(0.083)\end{array}$ & $\begin{array}{l}0.00 \mathrm{~d} \\
(1.59)\end{array}$ & $\begin{array}{l}33.33 \mathrm{bc} \\
(34.02)\end{array}$ & $\begin{array}{l}33.33 \mathrm{bcd} \\
(34.02)\end{array}$ & $\begin{array}{l}33.33 \mathrm{~cd} \\
(34.17)\end{array}$ \\
\hline $\mathrm{T}_{3}=$ Score $250 \mathrm{EC}$ & 86 & $\begin{array}{r}0.00 \mathrm{c} \\
(0.083)\end{array}$ & $\begin{array}{r}0.00 \mathrm{~d} \\
(0.083)\end{array}$ & $\begin{array}{c}0.00 \mathrm{c} \\
(0.083)\end{array}$ & $\begin{array}{r}0.00 \mathrm{~d} \\
(0.083)\end{array}$ & $\begin{array}{l}16.66 \mathrm{~d} \\
(17.05)\end{array}$ & $\begin{array}{l}16.67 \mathrm{de} \\
(17.05)\end{array}$ & $\begin{array}{l}16.67 \mathrm{de} \\
(17.05)\end{array}$ \\
\hline $\begin{array}{c}\mathrm{T}_{4}=\text { Pencozeb } 80 \\
\text { WP }\end{array}$ & 47 & $\begin{array}{c}0.00 \mathrm{c} \\
(0.083)\end{array}$ & $\begin{array}{r}0.00 \mathrm{~d} \\
(0.083)\end{array}$ & $\begin{array}{l}8.33 \mathrm{c} \\
(9.70)\end{array}$ & $\begin{array}{l}24.99 \mathrm{bc} \\
(25.53)\end{array}$ & $\begin{array}{l}33.33 \mathrm{bc} \\
(34.02)\end{array}$ & $\begin{array}{l}58.33 b \\
(48.10)\end{array}$ & $\begin{array}{l}66.66 \mathrm{~b} \\
(52.80)\end{array}$ \\
\hline $\begin{array}{c}\mathrm{T}_{5}= \\
\text { extract }\end{array}$ & 91 & $\begin{array}{c}0.00 \mathrm{c} \\
(0.083)\end{array}$ & $\begin{array}{r}0.00 \mathrm{~d} \\
(0.083)\end{array}$ & $\begin{array}{r}0.00 \mathrm{c} \\
(0.083)\end{array}$ & $\begin{array}{r}0.00 \mathrm{~d} \\
(0.083)\end{array}$ & $\begin{array}{c}0.00 \mathrm{e} \\
(0.083)\end{array}$ & $\begin{array}{l}24.99 \mathrm{~cd} \\
(25.53)\end{array}$ & $\begin{array}{l}33.33 \mathrm{~cd} \\
(34.01)\end{array}$ \\
\hline $\begin{array}{c}\mathrm{T}_{6}=\text { Allamunda } \\
\text { extract }\end{array}$ & 70 & $\begin{array}{c}0.00 \mathrm{c} \\
(0.083)\end{array}$ & $\begin{array}{r}0.00 \mathrm{~d} \\
(0.083)\end{array}$ & $\begin{array}{r}0.00 \mathrm{c} \\
(0.083)\end{array}$ & $\begin{array}{l}16.67 \mathrm{~cd} \\
(17.05)\end{array}$ & $\begin{array}{l}24.99 \mathrm{~cd} \\
(25.53)\end{array}$ & $\begin{array}{l}41.66 \mathrm{bc} \\
(38.71)\end{array}$ & $\begin{array}{l}49.99 b c \\
(43.41)\end{array}$ \\
\hline $\mathrm{T}_{7}=$ Vermi-compost & 44 & $\begin{array}{c}0.00 \mathrm{c} \\
(0.083)\end{array}$ & $\begin{array}{l}16.67 \mathrm{c} \\
(17.05)\end{array}$ & $\begin{array}{l}33.33 \mathrm{~b} \\
(34.02)\end{array}$ & $\begin{array}{l}41.66 \mathrm{~b} \\
(38.71)\end{array}$ & $\begin{array}{l}49.99 \mathrm{~b} \\
(43.41)\end{array}$ & $\begin{array}{l}58.33 b \\
(48.10)\end{array}$ & $\begin{array}{l}58.32 \mathrm{bc} \\
(48.10)\end{array}$ \\
\hline $\mathrm{T}_{8}=$ Poultry manure & 29 & $\begin{array}{r}16.67 \mathrm{~b} \\
(17.05)\end{array}$ & $\begin{array}{l}33.33 \mathrm{~b} \\
(34.02)\end{array}$ & $\begin{array}{l}41.66 \mathrm{~b} \\
(38.71)\end{array}$ & $\begin{array}{l}49.99 b \\
(43.41)\end{array}$ & $\begin{array}{l}49.99 \mathrm{~b} \\
(43.41)\end{array}$ & $\begin{array}{l}66.66 \mathrm{~b} \\
(52.80)\end{array}$ & $\begin{array}{l}66.66 \mathrm{~b} \\
(52.80)\end{array}$ \\
\hline $\mathrm{T}_{9}=T$. harzianum & 87 & $\begin{array}{l}0.00 \mathrm{c} \\
(0.083)\end{array}$ & $\begin{array}{r}0.00 \mathrm{~d} \\
(0.083)\end{array}$ & $\begin{array}{c}0.00 \mathrm{c} \\
(0.083)\end{array}$ & $\begin{array}{r}0.00 \mathrm{~d} \\
(0.083)\end{array}$ & $\begin{array}{l}16.66 \mathrm{~d} \\
(17.05)\end{array}$ & $\begin{array}{l}16.67 \mathrm{de} \\
(17.05)\end{array}$ & $\begin{array}{l}33.33 \mathrm{~cd} \\
(30.22)\end{array}$ \\
\hline $\mathrm{T}_{10}=$ Control & 10 & $\begin{array}{l}58.33 \mathrm{a} \\
(51.91)\end{array}$ & $\begin{array}{l}66.66 \mathrm{a} \\
(56.60)\end{array}$ & $\begin{array}{l}74.99 \mathrm{a} \\
(65.11)\end{array}$ & $\begin{array}{l}74.99 \mathrm{a} \\
(65.11)\end{array}$ & $\begin{array}{l}83.33 \mathrm{a} \\
(69.81)\end{array}$ & $\begin{array}{l}91.67 \mathrm{a} \\
(78.32)\end{array}$ & $\begin{array}{l}91.67 \mathrm{a} \\
(78.31)\end{array}$ \\
\hline LSD & - & 14.48 & 13.67 & 15.69 & 18.45 & 16.57 & 18.95 & 18.04 \\
\hline
\end{tabular}

Figures within same column having common letter(s) do not differ significantly at $1.00 \%$ level of significance.

Data within parenthesis are arc-sine transformed values. DDI: Days to disease initiation. 


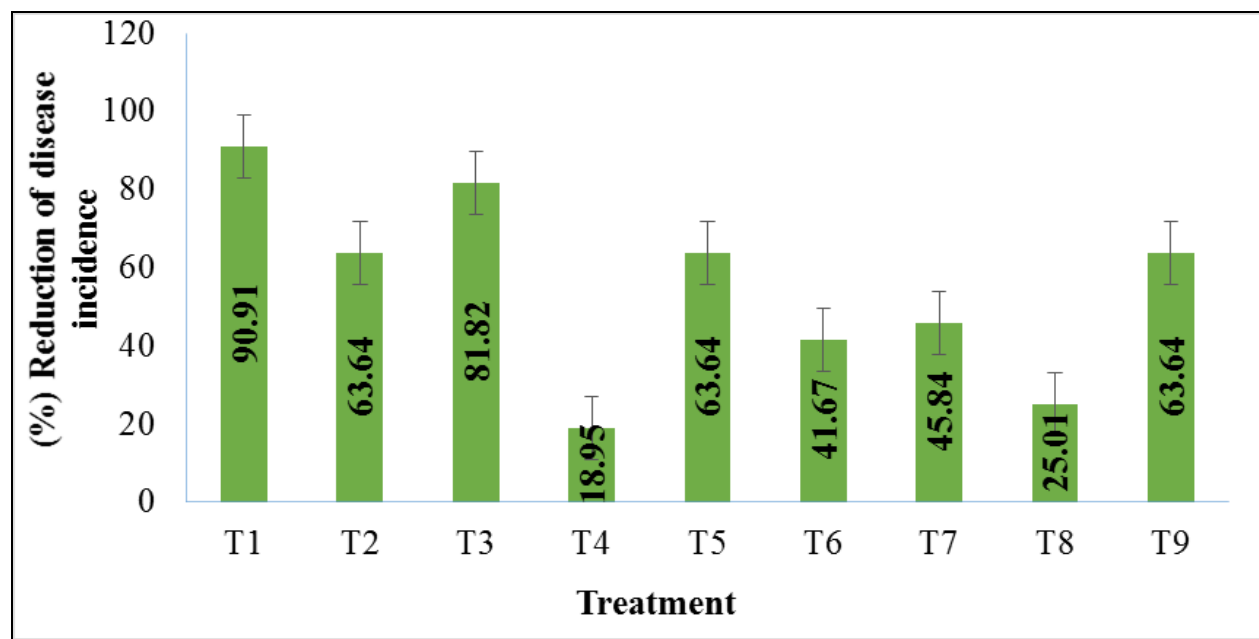

Figure 01. Percent reduction of incidence of foot and root rot disease of betel vine due to different treatments over control at 120 days after inoculation.

$\left[\mathrm{T}_{1}=\right.$ Provax 200, $\mathrm{T}_{2}=$ Tilt $-250 \mathrm{EC}, \mathrm{T}_{3}=$ Score $250 \mathrm{EC}, \mathrm{T}_{4}=$ Pencozeb $80 \mathrm{WP}, \mathrm{T}_{5}=$ Garlic clove extract, $\mathrm{T}_{6}=$ Allamanda leaf extract, $\mathrm{T}_{7}=$ Vermi-compost, $\mathrm{T}_{8}=$ Poultry manure, $\mathrm{T}_{9}=$ Tricoderma harzianum and $\mathrm{T}_{10}=$ Control (No chemicals, plant extract, bio-agents and soil amendments].

Table 2. Effect of fungicides, plant extracts, bio-agents and soil amendments on yield of beteleaf under field condition

\begin{tabular}{|c|c|c|}
\hline Treatments & $\begin{array}{l}\text { Yield (t/ha) } \\
\text { at } 120 \text { days }\end{array}$ & $\begin{array}{l}\text { Yield increase (\%) } \\
\text { over control }^{£}\end{array}$ \\
\hline$T_{1=}$ Provax 200 & $7.57 \mathrm{a}$ & 330.1 \\
\hline $\mathrm{T}_{2}=$ Tilt $-250 \mathrm{EC}$ & $6.59 \mathrm{abc}$ & 274.4 \\
\hline $\mathrm{T}_{3}=$ Score $250 \mathrm{EC}$ & $7.24 \mathrm{a}$ & 311.4 \\
\hline $\mathrm{T}_{4}=$ Pencozeb $80 \mathrm{WP}$ & $5.94 \mathrm{bcd}$ & 237.6 \\
\hline $\mathrm{T}_{5}=$ Garlic clove extract & $7.14 \mathrm{ab}$ & 300.5 \\
\hline $\mathrm{T}_{6}=$ Allamanda extract & 5.59 cde & 218.0 \\
\hline $\mathrm{T}_{7}=$ Vermi-compost & $5.29 \mathrm{de}$ & 201.0 \\
\hline $\mathrm{T}_{8}=$ Poultry manure & $4.48 \mathrm{e}$ & 154.5 \\
\hline $\mathrm{T}_{9}=T$. harzianum & $7.16 \mathrm{a}$ & 306.8 \\
\hline $\mathrm{T}_{10=}$ Control & $1.76 \mathrm{f}$ & - \\
\hline
\end{tabular}

\section{Conclusion}

Foot and root rot caused by Sclerotium rolfsii, the most devastating disease of betelvine in Bangladesh, reduced the yield and quality of betel leaves every year. Based on results of the in-vivo evaluation, Garlic clove extract, Provax-200 \& Score 250 EC fungicides, T. harzianum and soil amendments with Vermi- 
compost were found to be most effective against $S$. rolfsii which could be used as IPM components for increasing the yield of betel leaf under baroj conditions.

\section{References}

Ashrafuzzaman, H. and I. Hossain. 1992. Antifungal activity of crude extracts of plants against Rhizoctonia solani and Bipolaris sorokiniana. Proc, BAU. Res. Prog., 6: 188192.

BBS. 2018. Year Book of Agricultural Statistics of Bangladesh-2017, 29 ${ }^{\text {th }}$ Series. Bangladesh Bureau of Statistics, Statistics and Informatics Division, Ministry of Planning, Government of the Peoples' Republic of Bangladesh. 197 pp.

Dasgupta, B. and C. Sen. 1999. Assessment of Phytophthora root rot of betelvine and its management using chemicals. Indian J. Mycol. Pl. Pathol. 29: 91-95.

Dasgupta, B., P. K. Dutta, D. Padmanabhan and Satyabrata. 2005. Management of foot rot of betelvine. Indian J. Mycol. Plant Pathol., 33: 375-377.

Goswami, B.K., K.A. Kader, M.L. Rahman, M.R. Islam and P.K. Malaker. 2002. Development of leaf spot of betelvine caused by Colletotrichum capsici. Bangladesh J. Plant Pathol. 18(1\&2): 39-42.

Guha, P. and R.K. Jain. 1997. Status Report on Production, Processing and Marketing of Betel leaf (Piper betle L.). Agricultural and Food Engineering Department, IIT, Kharagpur, India, pp. 15-22.

Gupta, S.C and S.J. Kolte. 1982. A comparative study of isolates Macrophomina phaseolina from leaf and root of groundnut. Indian Phytopathol. 35: 619-623.

Islam, M.R. 2005. An integrated approach for the management of phomosis blight and fruit rot of eggplant. PhD. Thesis. Department of Plant Pathology, BAU, Mymensingh, Bangladesh. pp. 45-46.

Mian, I. H. (1995). Methods in Plant Pathology. IPSA-JICA Project Publication, 24, 100p.

Mukhopadhyay, A.N. 1994. Biocontrol of soil-borne plant pathogens current status, future prospects and potential limitations. Indian Phytopathol. 47(2): 199-126.

Pal, A.K. and K.C.B. Chowdhary. (1983). Control of some root diseases of sunhemp. Pesticides. 17: 9-10.

Parvin, R., M.R. Islam, M.S. Islam, N. Hasan, K. Begum and M.Z.K. Roni. 2016. Comparative efficacy of different fungicides against foot and root rot disease of betelvine caused by Sclerotium rolfsii. Bangladesh Res. Pub. J. 12(1): 09-15.

Punja, Z.K. 1985. The biology, ecology and control of Sclerotium rolfsii. Ann. Rev. Phytopath. 23: 97-118.

Rekha, D., M.B. Patil, P.S. Shetty, K.M. Swamy and R.B. Gamanagatti. 2012. In-vitro screening of native Trichoderma isolates against Sclerotium rolfsii causing collar rot of groundnut. Int. J. Sci. Nat. 3(1): 117-120.

Shahiduzzaman, M. 2015. Efficacy of fungicides and botanicals in controlling foot and root rot of lentil. Bangladesh J. Agril. Res. 40(4): 711-715

Yasmin, S. 2016. In-vitro evaluation of botanical extracts against some soil and seed borne fungi of economic importance. J. Agri. Ecolo. Res. Int. 8(2): 1-11. 
